\title{
Education and Digital Media Literacy: The Use of Digital Media by Teachers in Middle Schools
}

\author{
S Ramadhan ${ }^{1}$, E Sukma ${ }^{2}$, V Indriyani ${ }^{3}$ \\ \{syahrul_r@fbs.unp.ac.id ${ }^{1}$ \} \\ ${ }^{1}$ Faculty of Language and Art, Universitas Negeri Padang, Padang, Indonesia \\ ${ }^{2}$ Faculty of Education, Universitas Negeri Padang, Padang, Indonesia \\ ${ }^{3}$ Doctoral Program Student, Universitas Negeri Padang, Padang, Indonesia
}

\begin{abstract}
Knowledge and skills in using digital media are important for everyone, regardless of the occupation. One of them is a teacher. The use of various digital media can be useful for teachers in the learning process. Besides being useful for teachers as a means of delivering information, it is also useful for students in training to use digital media in the learning process. This study aims to determine the use of digital media in the learning process by the teacher. This research is a descriptive study using survey methods. The study sample was 112 Indonesian language teachers in West Sumatra. The research instruments used were questionnaires and interview guide sheets. The results of the study show that the media devices used have not been varied, policies that are known about the use of digital media have not been mastered, making many digital media creative content not mastered, the application of data transmission used has varied, and learning resources are still dominant through books. In general, the teacher agrees if the learning process uses online classes by relying on digital media. However, there are many obstacles if the policy is implemented, such as teacher competency, student competence, facilities and infrastructure, and other.
\end{abstract}

Keywords: digital media literacy, teacher, middle school

\section{Introduction}

The emergence of a rapidly developing information age and digital media will change the way users interact with information. The behavior of information use has changed dramatically with the advent of computers, the internet, and smartphones [1]. Technology creates a cultural space, where the role of the user is not clearly defined, whether as a sender or recipient. Interaction is the key word of the digital era [2]. The high level of consumption of media technology signifies the importance of thinking about media literacy [3]. This has an impact on the popular use of various technologies and digital media in various sectors of life, one of which is education [4].

Information and communication technology is present in almost a sophisticated technological and global society. There is rapid growth in the use of devices that support the Internet that facilitate web browsing and allow access to social media and cross-border communication [5]. Connectivity to the Internet and access to information available on the web offers commercial opportunities, greater participation and social awareness, and enables informed decisions [6]. Worldwide, technology enables more people to access learning resources and contribute to the development of knowledge and education improvement [7]. 
Digital literacy is variously referred to as internet literacy, cyber literacy, multimedia literacy, online literacy, and information literacy [8]. It can be defined as a capacity that supports users in engaging in social and cultural activities through the use of various media [3]. Digital literacy is needed to face transformation at all levels, including the level of communication, learning, satisfaction, curiosity, entertainment and recreation [9]. In general, this literacy framework can be reflected in the use of digital technology (various hardware and software technology and applications), communication tools (accurate digital products and services for information transmission purposes) and networks (as data transmission technology) to access, manage , integrating, evaluating, and creating information to function in the information society [10]. Therefore, the notion of literacy has evolved from having the competence to access, evaluate and understand static printed text to be able to access, discover, evaluate, understand and dynamically utilize digital text through the Internet [11].

This digital literacy approach also provides more interesting reasons for the use of technology in education [12]. Developing digital competencies effectively and efficiently, and to achieve digital literacy can be achieved with formal education. In formal education, teachers have a leading role[13]. Teachers must adapt their teaching methods so they can motivate students to engage in active participatory learning. It is important to develop new methods and innovative pedagogy to foster change in the educational paradigm [4].

Progress in the field of education in obtaining information using various digital media cannot be avoided. Teachers must have competence in selecting and using media in learning tailored to the needs of students [14][15]. The media is also adapted to learning tools such as text, tools and cutting-edge media technology [16]. Teachers can also cultivate critical thinking skills in students, and provide variation in the teaching process by holding various materials for students with different learning styles [17]. Therefore, this paper will explain the use of digital media by teachers in the learning process.

\section{Method}

This research is a descriptive study using survey methods [18]. Survey methods are defined as research methods that try to define cases as they are from research samples obtained from the study population. The study population consisted of Indonesian language teachers in West Sumatra who taught at the secondary school level [19]. The sample of this study was 112 teachers. In this study, sampling from the population used purposive sampling. The instrument used is a questionnaire in the form of a questionnaire consisting of 5 statements, in addition to that also used an interview guide sheet consisting of three questions. The instrument is used to find out the explanation of the correspondent regarding the use of digital media in the learning process [20].

\section{Result}

The results of this study aim to collect information on the use of digital media in learning. The results of the study were obtained through questionnaires by way of respondent choosing the options that represented their answers. Each correspondent is allowed to choose more than one option. Each option is assessed with a percentage of $100 \%$. The results of these studies are described as follows.

The results of this study are described based on the following indicators, including the use of digital

First, the media devices used by the teacher in the learning process are as follows. Computers were chosen as many as 82 people with a percentage of $73.21 \%$. Projectors was 
chosen as many as 66 people with a percentage of 58.93\%. The tablet PC was chosen as many as 24 people with a percentage of $21.43 \%$. Smart phones were chosen as many as 58 people with a percentage of $51.78 \%$. An interactive whiteboard was chosen as many as 22 people with a percentage of $19.64 \%$. Television was chosen as many as 12 people with a percentage of $10.71 \%$. The radio was chosen as many as 12 people with a percentage of $10.71 \%$. Based on these percentages, the media devices most used by teachers in learning are computers, projectors, and smart phones.

Second, the policies and rules of the media that are known to the teacher to be used in the interest of obtaining teaching material are as follows. The policy regarding copyright is known by the teacher as many as 82 people with a percentage of $73.21 \%$. The policy regarding illegal downloads is known by the teacher as many as 42 people with a percentage of $37.5 \%$. The policy regarding the behavior of dangerous media is known by the teacher as many as 38 people with a percentage of $33.93 \%$. The policy regarding the age limit of media users is known by the teacher as many as 54 people with a percentage of $48.21 \%$. Based on these data, in general more than $50 \%$ of teachers know about digital media copyrights used, while other policies are less known to teachers. This can be seen from the percentage that is below $50 \%$.

Third, digital media that can be made by the teacher for the learning process is as follows. Setting the blog was chosen as many as 12 people with a percentage of $10.71 \%$. Making images and photos selected as many as 39 people with a percentage of $34.82 \%$. Making videos was selected as many as 64 people with a percentage of 57.14\%. Making 64 recorded sound recordings with a percentage of $57.14 \%$. Making a concept map was chosen as many as 78 people with a percentage of $69.64 \%$. Making power points was chosen by 102 people with a percentage of $91.07 \%$. Based on these data, more teachers are able to make power points and at least create blogs for learning. So that the ability to make online media itself, is still rarely done by the teacher.

Fourth, the application used by teachers to share documents and various media used for the learning process is as follows. Google Drive was chosen by 30 people with a percentage of $26.79 \%$. Drop Boxes was chosen by 9 people with a percentage of $8.03 \%$. Email was chosen as many as 82 people with a percentage of $73.21 \%$. Whatsup selected 89 people with a percentage of $79.46 \%$. Line selected 15 people with a percentage of $13.39 \%$. Based on these data, more teachers use whatsup and gmail to send documents and various media for the learning process.

Fifth, the sources used by the teacher to obtain learning materials are as follows. Scientific articles was selected as many as 72 people with a percentage of $64.28 \%$. The print newspaper was selected as many as 58 people with a percentage of $51.78 \%$. Online newspapers were selected as many as 46 people with a percentage of $41.07 \%$. Blogs were selected as many as 44 people with a percentage of $39.28 \%$. The book was selected as many as 112 people with a percentage of $100 \%$. E-books was selected as many as 50 people with a percentage of $44.64 \%$. The magazine was chosen as many as 32 people with a percentage of $28.57 \%$. Based on these data, the teacher prefers to find learning resources through books rather than other sources.

In addition to the questionnaire, data was also obtained by interviewing Indonesian language teachers in West Sumatra who were teaching at the secondary school level. First, the learning process using online classes by relying on digital media in general teachers agree with this. The reasons include; the development of digital media is very rapid, must be adapted to the learning process by facilitating students to be not outdated; students will get information faster; the learning process carried out is more interesting, creative, efficient and innovative. However, online classes have several disadvantages. These weaknesses include; facilities and 
infrastructure must support the implementation of online classes; lack of direct interaction interaction during learning thereby reducing emotional closeness between teacher and student; the teacher must be able to control the content that is accessed by students during learning; and lack of interaction between students.

Second, the readiness of teachers to run online classes. Based on the question, the majority of teachers are ready to run online classes. The reasons include; the teacher must be able to keep up with the times to meet the needs of students in learning; the progress of digital media is now possible to carry out these activities; if it has become a policy, the teacher must be prepared to face the demands of work. However, the implementation of the online class can run optimally with the following requirements. (a) Teacher readiness, in this case teachers who will teach using online classes are teachers who have been literate with technology, not awkward and ready to learn to master technology. (b) Readiness of students. Students are the key to the success of online classroom learning, in this case they must be taught to be able to study online. Of course this requires a fairly long process, students must also be directed about the advantages of online classes. (c) Readiness of facilities and infrastructure. To use online classes, of course the school must complete facilities to support online classes, such as computers and internet availability. If the three factors can be implemented properly and correctly, learning to use online classes will work well.

Third, the use of digital media today in the learning process. In general, teachers have used digital media, although its use is still limited and has not varied. For example, teachers are more dominant using projectors connected to a laptop to display learning material rather than using a blackboard. Send assignments via email rather than hand-written assignments, and other examples.

\section{Discussion}

Defining media literacy is a complicated task. Media literacy is increasingly plural and multiplied in educational discourse. Various media appear, making it easier for teachers to choose media that can be used in the learning process. Based on the data obtained, the use of computers, projectors, and smart phones is the choice of tools that many teachers choose in the learning process. This is possible because computers make it easier for teachers to present teaching material to students with the help of a projector. Computers and smart phones make it easy for teachers to search for various sources and learning media with the help of the internet. In accordance with statement [3], digital media can create learning in a new way, users can compile text by combining writing, still images and moves, sounds, movements, meanings and narratives. This convenience can help teachers to create learning that is innovative and fun, and can be understood by students.

Live in a multimedia era where the majority of information received by people is less often from print sources and more usually from highly constructed visual images, complex sound settings, and various media formats. The influential role of media plays in organizing, forming, and disseminating information, ideas, and values creating strong public pedagogies [21]. Based on the data obtained, teachers are more dominant able to make power points, while making learning media less than $60 \%$, especially making blogs, only with a percentage of $10.71 \%$. So that it can be concluded that the media that can be made by teachers is still not very diverse. The data is also in accordance with other data, that for learning resources used by teachers more dominant comes from books than other sources. So the teacher is still dominant using print sources rather than online sources. 
Social media produces various ways to communicate with anyone through messages, images, audio and video based content [22]. This shift to social media communication is associated with increased availability of digital and cellular interfaces that influence the way people interact with each other through social media and other communication platforms [23]. It also affects education. In the process of sending and receiving data, both teachers and teachers, teachers and students or vice versa have used various media. Gmail and whatsup applications are more widely used than other applications. The choice of this media is also influenced by the ease of use and adaptation to the needs of the user.

Digital media makes it easy for teachers to teach. The teacher can obtain various kinds of information and media for the benefit of learning. However, the use of such media can involve problems such as ethics, moral values, law and security that need to be seriously considered so that all media users can productively produce and produce media works [3]. Based on the data obtained, the presentation of the teacher's understanding of the policy of using digital media is very low. This needs to be considered by various parties in the education environment to understand wisely in using the media. If the teacher does not know about the policy, it will adversely affect students as recipients of information in the learning process.

The use of digital media now makes it possible for education to carry out the online learning process. Based on interviews conducted with the teacher, in general the teacher agrees if there is a policy to carry out the learning process online, because the teacher must be able to adjust to the times. However, to make this happen in Indonesia it is still difficult to implement it evenly. Teacher competencies, school facilities and infrastructure, learning resources, media and internet networks have not spread evenly in every region in Indonesia. Williamson sees the curriculum as the core canon or the main content of the content to see the curriculum as a hyperlink with network digital media, popular culture, and daily interactions. Based on these statements, changes in the curriculum, the learning process can change due to technological advances and the use of diverse digital media [24]. Therefore, the teacher must always strive to improve his knowledge, not only material, but in the use of media and learning methods that are suitable for the current and future needs of students. In education, students do not follow the wishes of the teacher, but the teacher must be able to teach students according to the needs of students.

\section{Conclusions}

Today, the world has entered the digital era. This was marked by the use of communication and information technology in various sectors of life, one of which was education. Based on the results of the study it can be concluded as follows. First, the media devices most used by teachers in learning are computers, projectors, and smart phones. Secondly, teachers generally know about the policies regarding digital media copyright that are used, while other policies are less known to the teacher. Third, teachers are more able to make power points and at least make blogs for learning, so the ability to create online media itself is rarely done by teachers. Fourth, teachers use more whatsup and gmail to send documents and various media for the learning process. Fifth, teachers prefer to find learning resources through books rather than other sources. Sixth, the teacher generally agrees if the learning process uses online classes by relying on digital media. However, there are many obstacles if the policy is implemented, such as teacher competency, student competence, facilities and infrastructure, and others.

\section{Acknowledgements}


A sincere thanks goes to all respondents, namely Indonesian teachers in West Sumatra who have been involved in questionnaires and interviews.

\section{References}

[1] Y. Noh, "A study on the effect of digital literacy on information use behavior," $J$. Librariansh. Inf. Sci., vol. 49, no. 1, pp. 26-56, 2017.

[2] J. Suoranta, "Breaking radical monopolies: towards political economy of digital literacy," E-Learning, vol. 1, no. 2, pp. 283-301, 2004.

[3] S. B. Baboo, "Media literacy in the lifeworlds of malaysian children," Glob. Stud. Child., vol. 3, no. 1, pp. 72-85, 2013.

[4] A. Y. L. Lee, "Media education in the School 2.0 era: Teaching media literacy through laptop computers and iPads," Glob. Media China, vol. 1, no. 4, pp. 435-449, 2016.

[5] M. S. Khalid, Pedersen, and M. J. Lykkegaard, "Digital exclusion in higher education contexts: a systematic literature review," Procedia - Soc. Behav. Sci., vol. 228, pp. 614-621, 2016.

[6] T. P. N. T. Shariman, N. A. Razak, and N. F. M. Noor, "Digital literacy competence for academic needs: an analysis of Malaysian students in three universities.," Procedia - Soc. Behav. Sci., vol. 69, pp. 1489-1496, 2012.

[7] V. Dragoş and V. Mih, "Scientific literacy in school," Procedia - Soc. Behav. Sci., vol. 209, pp. 167-172, 2015.

[8] E. Huerta and R. Sandofal-Almazan, "Digital literacy: Problems faced by telecenter users in Mexico," Inf. Technol. Dev., vol. 13, no. 3, pp. 217-232, 2007.

[9] A. P. Vélez and I. I. Zuazua, "Digital literacy and cyberconvivencia in primary education," Procedia - Soc. Behav. Sci., vol. 237, pp. 110-117, 2017.

[10] B. O'Connor, Digital transformation: A framework for ICT literacy. USA: ETS, 2017.

[11] J. Coiro, M. Knobel, C. Lankshear, and D. J. Lew, "Central issues in new literacies and new literacies research," in Handbook of Research on New Literacies, CoiroJ, K. M, L. C, and L. D. J, Eds. New York: Lawrence Erlbaum Associates, Taylor \& Francis Group, 2008, pp. 1-21.

[12] D. Buckingham, "Digital Media Literacies: rethinking," Res. Compart. Int. Educ., vol. 2, no. 1, pp. 43-55, 2007.

[13] M. Csernoch and P. Biró, "The power in digital literacy and algorithmic skill," Procedia - Soc. Behav. Sci., vol. 174, pp. 550-559, 2015.

[14] C. Erdem and B. Erişti, "Paving the way for media literacy instruction in preservice teacher education: prospective teachers' levels of media literacy," Int. J. Instr., vol. 11, no. 4, pp. 795-810, 2018.

[15] Atmazaki and V. Indriyani, "Digital literacy competencies for teacher education students," in Advances in Social Science, Education and Humanities Research, 2019, vol. 335, pp. 1010-1018.

[16] N. Westbrook, "Media literacy pedagogy: Critical and new/twenty-first-century literacies instruction," E-Learning Digit. Media, vol. 8, no. 2, pp. 154-164, 2011.

[17] F. W. Baker, "Media literacy: 21st century literacy skills," in Curriculum 21: Essential education for a changing world, Hayes J, Ed. Alexandria: ASCD, 2010, pp. 133--152.

[18] C. W. Irwin and E. T. Stafford, Survey methods for educators : Collaborative survey development (part 1 of 3). Washington, DC: U.S: Department of Education, Institute of Education Sciences, National Center for Education Evaluation and Regional 
Assistance, Regional Educational Laboratory Northeast \& Islands, 2016.

[19] A. M. Pazzaglia, E. T. Stafford, and S. M. Rodriguez, Survey methods for educators : Selecting samples and administering surveys (part 2 of 3). Washington, DC: U.S: Department of Education, Institute of Education Sciences, National Center for Education Evaluation and Regional Assistance, Regional Educational Laboratory Northeast \& Islands, 2016.

[20] J. Walston, J. Redford, and M. P. Bhatt, Workshop on survey methods in education research: facilitator's guide and resources. Washington, DC: U.S: Department of Education, Institute of Education Sciences, National Center for Education Evaluation and Regional Assistance, Regional Educational Laboratory Midwest, 2017.

[21] D. Kellner and J. Share, "Critical media literacy: Crucial policy choices for a twentyfirst-century democracy," Policy Futur. Educ., vol. 5, no. 1, pp. 59-69, 2007.

[22] R. Wilding, "“ Virtual' intimacies ? Families communicating," Glob. Networks, vol. 2, pp. 125-142, 2006.

[23] J. M. Marlowe, A. Bartley, and F. Collins, "Digital belongings: The intersections of social cohesion, connectivity and digital media," Ethnicities, vol. 17, no. 1, pp. 85$102,2017$.

[24] William B, The future of curriculum: School knowledge in digital age. London: The MIT Press, 2013. 